Article

\title{
Prorocentrolide-A from Cultured Prorocentrum lima Dinoflagellates Collected in Japan Blocks Sub-Types of Nicotinic Acetylcholine Receptors
}

\author{
Muriel Amar ${ }^{1,+}$, Rómulo Aráoz ${ }^{1,2,+}$, Bogdan I. Iorga ${ }^{3}$ (D) , Takeshi Yasumoto ${ }^{4}$, Denis Servent ${ }^{1}$ \\ and Jordi Molgó 1,2,*(i) \\ 1 Commissariat à l'énergie Atomique et aux énergies Alternatives (CEA), Institut des Sciences du Vivant \\ Frédéric Joliot, Service d'Ingénierie Moléculaire des Protéines, Université Paris-Saclay, Bâtiment 152, \\ 91191 Gif-sur-Yvette, France; muriel.amar@cea.fr (M.A.); romulo.araoz@cea.fr (R.A.); \\ denis.servent@cea.fr (D.S.) \\ 2 Institut des Neurosciences Paris-Saclay, UMR 9197 CNRS-Université Paris-Sud, 91198 Gif-sur-Yvette, France \\ 3 CNRS, Institut de Chimie des Substances Naturelles, UPR 2301, Labex LERMIT, 91198 Gif-sur-Yvette, France; \\ bogdan.iorga@cnrs.fr \\ 4 Japan Food Research Laboratories, 6-11-10 Nagayama, Tama, Tokyo 206-0025, Japan; yasumotot@jfrl.or.jp \\ * Correspondence: jordi.molgo@cea.fr; Tel.: +33-1-6908-5158; Fax: +33-1-6908-9071 \\ + These authors contributed equally to this work.
}

Received: 29 January 2018; Accepted: 23 February 2018; Published: 28 February 2018

\begin{abstract}
Prorocentrolides are members of the cyclic imine phycotoxins family. Their chemical structure includes a 26-membered carbo-macrocycle and a 28-membered macrocyclic lactone arranged around a hexahydroisoquinoline that incorporates the characteristic cyclic imine group. Six prorocentrolides are already known. However, their mode of action remains undetermined. The aim of the present work was to explore whether prorocentrolide-A acts on nicotinic acetylcholine receptors (nAChRs), using competition-binding assays and electrophysiological techniques. Prorocentrolide-A displaced $\left[{ }^{125} \mathrm{I}\right] \alpha$-bungarotoxin binding to Torpedo membranes, expressing the muscle-type $\left(\alpha 1_{2} \beta 1 \gamma \delta\right) \mathrm{nAChR}$, and in HEK-293 cells, expressing the chimeric chick neuronal $\alpha 7-5 \mathrm{HT}_{3} \mathrm{nAChR}$. Functional studies revealed that prorocentrolide- $\mathrm{A}$ had no agonist action on nAChRs, but inhibited ACh-induced currents in Xenopus oocytes that had incorporated the muscle-type $\alpha 1_{2} \beta 1 \gamma \delta \mathrm{nAChR}$ to their membranes, or that expressed the human $\alpha 7 \mathrm{nAChR}$, as revealed by voltage-clamp recordings. Molecular docking calculations showed the absence of the characteristic hydrogen bond between the iminium group of prorocentrolide- $\mathrm{A}$ and the backbone carbonyl group of Trp147 in the receptor, explaining its weaker affinity as compared to all other cyclic imine toxins. In conclusion, this is the first study to show that prorocentrolide-A acts on both muscle and neuronal nAChRs, but with higher affinity on the muscle-type nAChR.
\end{abstract}

Keywords: prorocentrolides; dinoflagellate toxin; cyclic imine toxins; nicotinic acetylcholine receptors; Xenopus oocytes; nicotinic currents; binding assays; molecular docking

Key Contribution: The present study is the first to show that prorocentrolide-A blocks the Torpedo muscle-type $\alpha 1_{2} \beta 1 \gamma \delta \mathrm{nAChR}$ and the human $\alpha 7 \mathrm{nAChR}$ incorporated or expressed, respectively, in Xenopus oocytes.

\section{Introduction}

A large number of marine dinoflagellate species of the genus Prorocentrum, distributed in benthic and planktonic habitats, have been described [1,2]. Among these dinoflagellates Prorocentrum lima and Dinophysis spp. are abundantly distributed worldwide in tropical to temperate and cold waters 
regions [3-5], and are known to produce a number of bioactive compounds [6]. These compounds include: okadaic acid and its analogues [7,8], and the associated dinophysistoxins (DTX1 and DTX2) [9,10], which can also occur as complex assortments of esters derivatives [11], and are the main toxins responsible for incidents of diarrheic shellfish poisoning (DSP) [12-17]. Okadaic acid and its analogues are highly-specific inhibitors of serine/threonine protein phosphatases PP1 and PP2A [18-20]. Additionally, these toxins are potent tumor promoters [21-24], and can induce genotoxicity in some cell types [25-28].

The dinoflagellate Prorocentrum lima has been recognized to produce also some other bioactive compounds including: the prorocentrolide [29], spiro-prorocentrimine [30], prorocentin [31], the formosalides [32], and the limaol polyketide [33]. Interestingly, the analysis of extracts obtained from cultured Prorocentrum lima dinoflagellates allowed the first chemical and structural identification of the macrocyclic compound named prorocentrolide, which is a "fast-acting toxin" due to the rapid onset of neurological symptoms, followed by paralysis and death after intraperitoneal administration in mouse bioassays for detecting lipid soluble toxins [29]. Such symptoms were completely different from those reported with diarrheic toxins. Further studies using bioassay-guided fractionation of extracts of the dinoflagellate Prorocentrum maculosum Faust, allowed the chemical characterization of prorocentrolide-B in those extracts [34]. Recently, a new tropical toxic benthic dinoflagellate species (Prorocentrum caipirignum), related to the P. lima species complex, has been reported to produce both okadaic acid and the fast acting prorocentrolide toxin [35].

Prorocentrolides are members of the cyclic imine family of phycotoxins that are known to contaminate seafood, and which includes the gymnodimines, spirolides, pinnatoxins, portimine, pteriatoxins, and spiro-prorocentrimine (reviewed in [36-39]). Some of these cyclic imine toxins have been reported to be potent antagonists of muscle- and neuronal-types of nicotinic acetylcholine receptors (nAChRs), as recently reviewed [40].

The chemical structure of prorocentrolides comprises a 26-membered carbo-macrocycle and a 28-membered macrocyclic lactone arranged around a hexahydroisoquinoline that incorporates the characteristic cyclic imine group (Figure 1). At present, as shown in Table 1, six prorocentrolides are already known which differ by their chemical structures.

Despite the fact that prorocentrolide-A was the first cyclic imine toxin discovered (already in 1988 [29]), and that it has been reported in several Prorocentrum species [34,35], its mode of action remains unknown. There are several reasons for this: (i) the production by dinoflagellates is very limited; (ii) not all P. lima species seem to produce the compound; and (iii) the ecological conditions that may favor the production of prorocentrolides remain unknown.

To the best of our knowledge the possibility that prorocentrolide-A could target nAChRs has not been previously investigated. Consequently, the aim of the present study was to examine whether prorocentrolide-A acted on nAChRs. For this, we used heterologous expression of nAChRs on both Xenopus laevis oocytes and HEK-293 cells, and Torpedo electric organ membranes together with voltage-clamp recordings and binding assays. The present study shows for the first time that prorocentrolide-A acts on both muscle-type $\left(\alpha 1_{2} \beta 1 \gamma \delta\right)$ and neuronal human $\alpha 7$ and chick chimeric $\alpha 7-5 \mathrm{HT}_{3} \mathrm{nAChRs}$. Differences in affinity are discussed based on molecular docking calculations performed with the extracellular domain of these receptors subtypes. 


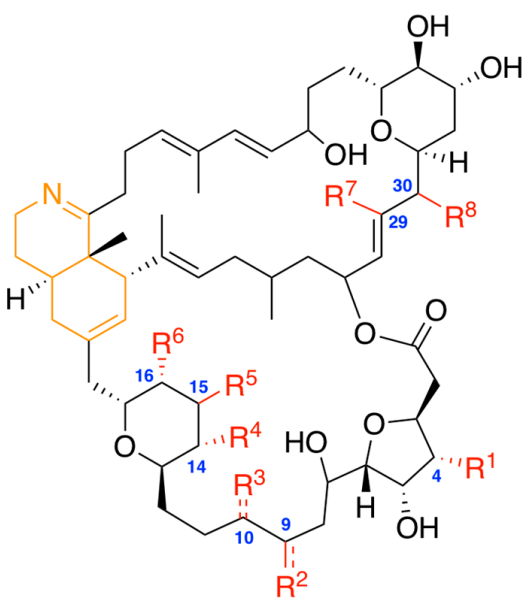

Figure 1. General chemical structure of prorocentrolides and analogues. The nature of substituents $\mathrm{R}^{1}$ to $\mathrm{R}^{8}$ (colored in red) is detailed in Table 1 . The cyclic imine group is colored in orange.

Table 1. Prorocentrolides and analogues that have been reported to date.

\begin{tabular}{ccccccccc}
\hline Prorocentrolide & $\mathbf{R}^{\mathbf{1}}$ & $\mathbf{R}^{\mathbf{2}}$ & $\mathbf{R}^{\mathbf{3}}$ & $\mathbf{R}^{\mathbf{4}}$ & $\mathbf{R}^{\mathbf{5}}$ & $\mathbf{R}^{\mathbf{6}}$ & $\mathbf{R}^{\mathbf{7}}$ & $\mathbf{R}^{\mathbf{8}}$ \\
\hline Prorocentrolide-A & $\mathrm{H}$ & $\mathrm{CH}_{2}=$ & $\mathrm{H}$ & $\mathrm{OH}$ & $\mathrm{OH}$ & $\mathrm{H}$ & $\mathrm{CH}_{3}$ & $\mathrm{OH}$ \\
30-sulfate prorocentrolide & $\mathrm{H}$ & $\mathrm{CH}_{2}=$ & $\mathrm{H}$ & $\mathrm{OH}$ & $\mathrm{OH}$ & $\mathrm{H}$ & $\mathrm{CH}_{3}$ & $\mathrm{OSO}_{3} \mathrm{H}$ \\
4-hydroxy prorocentrolide & $\mathrm{OH}$ & $\mathrm{CH}_{2}=$ & $\mathrm{H}$ & $\mathrm{OH}$ & $\mathrm{OH}$ & $\mathrm{H}$ & $\mathrm{CH}_{3}$ & $\mathrm{OH}$ \\
9,51-dihydro prorocentrolide & $\mathrm{H}$ & $\mathrm{CH}_{3}$ & $\mathrm{H}$ & $\mathrm{OH}$ & $\mathrm{OH}$ & $\mathrm{H}$ & $\mathrm{CH}$ & $\mathrm{OH}$ \\
14-O-acetyl-4-hydroxy prorocentrolide & $\mathrm{OH}$ & $\mathrm{CH}_{2}=$ & $\mathrm{H}$ & $\mathrm{OC}(=\mathrm{O}) \mathrm{CH}_{3}$ & $\mathrm{OH}$ & $\mathrm{H}$ & $\mathrm{CH}$ & $\mathrm{OH}$ \\
Prorocentrolide-B & $\mathrm{OSO}_{3} \mathrm{H}$ & $\mathrm{CH}_{3}$ & $\mathrm{CH}_{2}=$ & $\mathrm{OH}$ & $\mathrm{H}$ & $\mathrm{OH}$ & $\mathrm{H}$ & $\mathrm{OH}$ \\
\hline
\end{tabular}

* See Figure 1 for the general chemical structure.

\section{Results}

\subsection{Effect of Prorocentrolide-A on Xenopus Oocytes after Heterologous Expression of the Human $\alpha 7 n A C h R$}

The effect of prorocentrolide-A was investigated in Xenopus oocytes that have been previously transfected with the human $\alpha 7 \mathrm{nAChR}$. Two to five days after transfection, oocytes were impaled with two microelectrodes and voltage-clamped at $-60 \mathrm{mV}$ holding membrane potential. Perfusion of $350 \mu \mathrm{M}$ acetylcholine (ACh) (which corresponds to the $\mathrm{EC}_{50}$ for $\mathrm{ACh}$ ) for $3 \mathrm{~s}$ elicited phasic inward nicotinic currents, which varied in peak amplitude between $0.2 \mu \mathrm{A}$ and $3 \mu \mathrm{A}$ among oocytes studied, and rapidly inactivated ( $n=45$ oocytes tested from eight different Xenopus donors). As shown in Figure 2A, twin control perfusions of ACh evoked the typical phasic inward currents that had similar amplitudes when spaced by a 3 min time interval. Prorocentrolide-A when perfused at concentration ranging from $3 \times 10^{-9} \mathrm{M}$ to $4 \times 10^{-4} \mathrm{M}$ had no detectable agonist action on the $\alpha 7 \mathrm{nAChR}$ (Figure 2A), but dose-dependently decreased the peak amplitude of the ACh-elicited current, as shown in Figure $2 \mathrm{~B}$. The inhibitory action of Prorocentrolide-A had an $\mathrm{IC}_{50}=1660 \mathrm{nM}$ (1641-1680 nM, 95\% confidence intervals, 45 oocytes, from eight Xenopus donors).

\subsection{Effect of Prorocentrolide-A on Xenopus Oocytes after Microtransplantation of Torpedo Muscle-Type $\alpha 1_{2} \beta 1 \gamma \delta n A C h R$}

Further studies were performed on Xenopus oocytes that have been micro-transplanted with purified membranes from the electric organ of Torpedo containing the muscle-type $\left(\alpha 1_{2} \beta 1 \gamma \delta\right) \mathrm{nAChR}$. After a few days, once the $\alpha 1_{2} \beta 1 \gamma \delta \mathrm{nAChR}$ have been incorporated to the oocyte membrane, oocytes were voltage-clamped at $-60 \mathrm{mV}$. For $\mathrm{nAChR}$ activation, the perfusion of $\mathrm{ACh}$ was used at the concentration corresponding to its experimentally-determined $\mathrm{EC}_{50}(25 \mu \mathrm{M})$. Prorocentrolide-A, by itself, did not evoke any inward current in the range of concentrations tested $\left(10^{-10_{-}} 10^{-4} \mathrm{M}\right)$ indicating that it had no agonist action on the $\alpha 1_{2} \beta 1 \gamma \delta \mathrm{nAChR}$. However, it dose-dependently reduced 
the peak amplitude of the ACh-evoked currents, with an $\mathrm{IC}_{50}=185.7 \mathrm{nM}(165-209 \mathrm{nM}, 95 \%$ confidence intervals, 36 oocytes, from nine Xenopus donors).

A

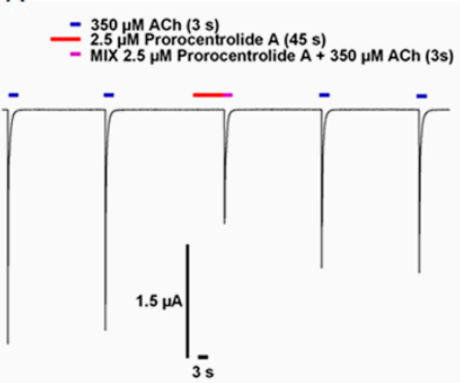

B

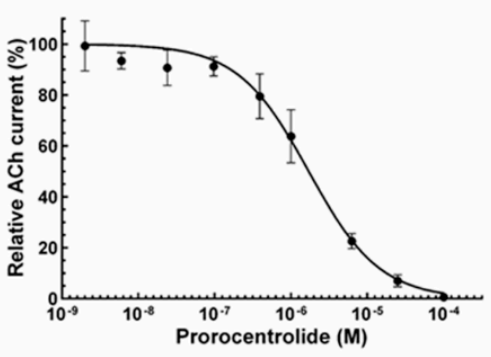

Figure 2. Effect of prorocentrolide-A on the human $\alpha 7 \mathrm{nAChR}$ expressed in Xenopus oocytes. (A) Typical inward nicotinic currents evoked by ACh $(350 \mu \mathrm{M})$ applied for $3 \mathrm{~s}$ and recorded at $-60 \mathrm{mV}$ holding membrane potential. The blue tracings above the current traces denote the perfusion of $\mathrm{ACh}$. The red tracing (above the current trace) denotes the perfusion of $2.5 \mu \mathrm{M}$ prorocentrolide-A. Note that no current was evoked by the perfusion of the prorocentrolide alone, which indicates that it has no direct agonist action on the $\alpha 7$-receptor, while when applied together with ACh (red and blue tracing, MIX, 3rd current trace from left) a block of the peak inward current was observed. The washout of the prorocentrolide from the medium by the fast perfusion system allowed a partial recovery of the ACh evoked current (4th and 5th current tracings) as compared to the control currents (first two tracings). (B) Concentration-dependent inhibition of ACh-elicited nicotinic currents by prorocentrolide-A in oocytes expressing the human $\alpha 7 \mathrm{nAChR}$. Peak amplitudes of ACh-evoked currents (mean \pm SEM), recorded at $-60 \mathrm{mV}$ in the presence of the prorocentrolide were normalized to control currents, and fitted to the Hill equation $(n \mathrm{H}=0.93)$. The concentration of $\mathrm{ACh}$ used was the $\mathrm{EC}_{50}$ determined.

\subsection{Competition-Binding Assays between Prorocentrolide-A and Radiolabeled $\alpha$-Bungarotoxin}

Additional information on the interaction between prorocentrolide-A and nAChRs was obtained by competition-binding assays at equilibrium, which allowed the characterization of the binding affinity and the antagonist potency of the phycotoxin. For this, purified Torpedo membranes expressing the muscle-type $\alpha 1_{2} \beta 1 \gamma \delta \mathrm{nAChR}$, and HEK-293 cells expressing the chimeric chick neuronal $\alpha 7-5 \mathrm{HT}_{3}$ $\mathrm{nAChR}$ were used together with $\left[{ }^{125} \mathrm{I}\right] \alpha-\mathrm{BTX}$, as radiotracer. Figure 3 , shows that prorocentrolide-A concentration-dependently displaced $\left[{ }^{125} \mathrm{I}\right] \alpha$-BTX from the Torpedo muscle-type receptor, and from neuronal $\alpha 7-5 \mathrm{HT}_{3}$ nAChR expressed in HEK-293 cells, but with much less efficacy than the high affinity $\alpha$-cobratoxin from Naja kaouthia.
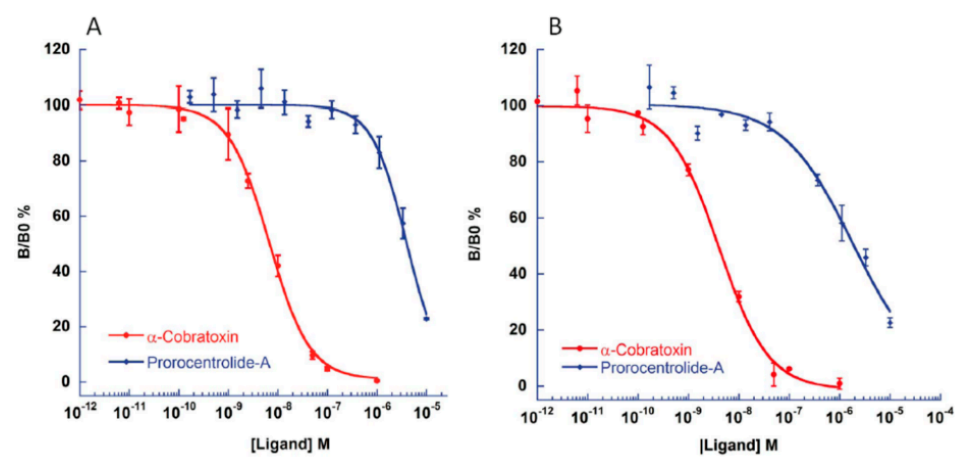

Figure 3. Prorocentrolide-A and $\alpha$-cobratoxin displaced, in a concentration-dependent manner, the specific $\left[{ }^{125} \mathrm{I}\right] \alpha-\mathrm{BTX}$ binding to HEK-293 cells, expressing the chimeric chick neuronal $\alpha 7-5 \mathrm{HT}_{3}$ $\mathrm{nAChR}(\mathbf{A})$ and to Torpedo membranes expressing the muscle-type $\alpha 1_{2} \beta 1 \gamma \delta \mathrm{nAChR}$; and (B) each point in the curves represents the mean \pm SEM of three different experiments performed in duplicate. 
From the binding-competition curves of Figure 3, it was possible to calculate the affinity constants (see the Materials and Methods section) shown in Table 2. Prorocentrolide-A interacted with nanomolar affinity with the muscle-type $\alpha 1_{2} \beta 1 \gamma \delta \mathrm{nAChR}$, but with much lower affinity than the $\alpha$-cobratoxin which exhibited sub-nanomolar affinity on this receptor subtype. As disclosed on Table 2, prorocentrolide-A interacted with much lower affinity with the neuronal $\alpha 7-5 \mathrm{HT}_{3} \mathrm{nAChR}$.

Table 2. Affinity constants ( $\mathrm{Ki} \pm \mathrm{SEM}, \mathrm{nM})$ of prorocentrolide-A, and the comparison to the nicotinic antagonist $\alpha$-cobratoxin from Naja kaouthia, and to other cyclic imine toxins previously studied. Data was obtained in competition binding assays at equilibrium on Torpedo muscle-type $\alpha 1_{2} \beta 1 \gamma \delta$ and chimeric chick $\alpha 7-5 \mathrm{HT}_{3} \mathrm{nAChR}$. Values on Hill coefficients $(n \mathrm{H})$ are included below Ki values.

\begin{tabular}{cccc}
\hline Nicotinic Antagonist & $\mathbf{\alpha 1}_{\mathbf{2}} \boldsymbol{\beta} \mathbf{1} \boldsymbol{\gamma} \boldsymbol{\delta}$ & $\boldsymbol{\alpha 7 - 5 \mathbf { H T } _ { \mathbf { 3 } }}$ & Reference \\
\hline Prorocentrolide-A & $\begin{array}{c}81.70 \pm 16.1^{\mathrm{a}} \\
\left(n \mathrm{H}=0.66 \pm 0.27^{\mathrm{b}}\right)\end{array}$ & $\begin{array}{c}3380.0 \pm 695 \\
(n \mathrm{H}=1.19 \pm 0.4)\end{array}$ & This work \\
\hline$\alpha$-cobratoxin & $\begin{array}{c}0.397 \pm 0.153 \\
(n \mathrm{H}=0.89 \pm 0.06)\end{array}$ & $\begin{array}{c}5.60 \pm 0.19 \\
(n \mathrm{H}=1.02 \pm 0.07)\end{array}$ & This work \\
\hline 13,19-didesmethyl spirolide C & $0.017 \pm 0.003$ & $0.22 \pm 0.06$ & {$[41]$} \\
\hline 20-methyl spirolide G & $0.028 \pm 0.005$ & $0.11 \pm 0.08$ & {$[42]$} \\
\hline 13-desmethyl spirolide C & $0.080 \pm 0.002$ & $0.53 \pm 0.08$ & {$[43]$} \\
\hline Gymnodimine-A & $0.23 \pm 0.08$ & $0.33 \pm 0.08$ & {$[44]$} \\
\hline Pinnatoxin-A & $2.80 \pm 0.03$ & $0.35 \pm 0.04$ & {$[45]$} \\
\hline
\end{tabular}

a Data are presented as the mean \pm SEM from three distinct experiments performed in duplicate; ${ }^{\mathrm{b}}$ Data on the Hill coefficients $(n \mathrm{H})$ are presented as the mean \pm SEM from three distinct experiments performed in duplicate.

\subsection{Molecular Docking Interactions between Prorocentrolide-A and the Extracellular Domain of Muscle-Type} $\alpha 1_{2} \beta 1 \gamma \delta$ and Neuronal $\alpha 7 n A C h R$

The protocol described previously $[41,42,45]$ was used for the docking of prorocentrolide at the intersubunit interface of the extracellular domain of $\alpha 1_{2} \beta 1 \gamma \delta$ and $\alpha 7 \mathrm{nAChRs}$, with one significant change. The existing conformations of the $\mathrm{nAChR}$ could not accommodate the unusual size of the prorocentrolide-A ligand. Therefore, the docking calculations were carried out in the absence of the $C$ loop, which was added subsequently in a conformation that was compatible with the presence of the ligand within the binding site. The best docking conformations are presented in Figure 4 .
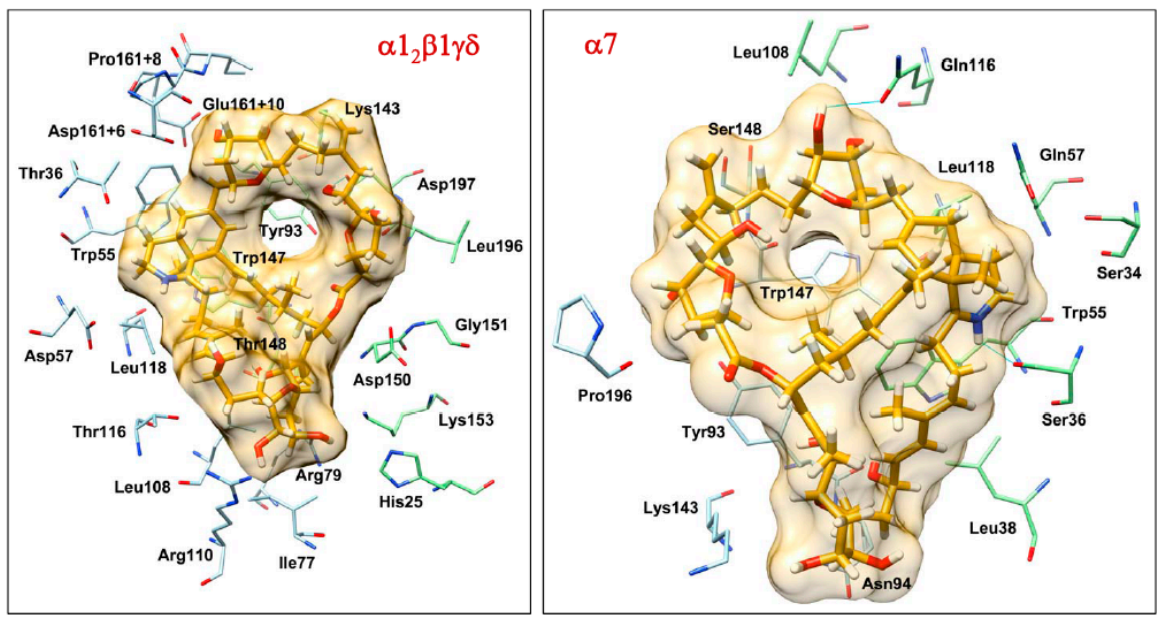

Figure 4. Docking conformations of prorocentrolide-A at the subunit interface of muscle-type (left) and neuronal $\alpha 7$ nAChR (right). Residues within $4 \AA$ from the ligand are shown. Loop $C$ is hidden for more clarity. 


\section{Discussion}

Using both electrophysiological voltage-clamp techniques and competition ligand-binding assays, present results show that prorocentrolide-A targets both heteropentameric muscle-type $\alpha 1_{2} \beta 1 \gamma \delta$ $\mathrm{nAChR}$ and homopentameric neuronal- $\alpha 7 \mathrm{nAChRs}$. These ligand-gated ion channels mediate fast transmission at the skeletal neuromuscular junction and in the central and peripheral nervous systems, respectively (reviewed in $[46,47]$ ).

Prorocentrolide-A, in contrast to ACh (the endogenous agonist of nAChRs), had no agonist properties on both $\alpha 1_{2} \beta 1 \gamma \delta$ and $\alpha 7 \mathrm{nAChRs}$ incorporated or expressed in the oocyte membrane, respectively, but blocked the inward current evoked by ACh. Ligand-binding assays, performed on membranes and cells expressing the different nAChR subtypes, using $\left[{ }^{125} \mathrm{I}\right] \alpha$-BTX and standard methods, allowed a better understanding of the interaction between prorocentrolide-A and nAChRs. These competition-binding assays demonstrated the concentration-dependent displacement of $\left[{ }^{125} \mathrm{I}\right] \alpha$-BTX from Torpedo membranes expressing the muscle-type $\alpha 1_{2} \beta 1 \gamma \delta \mathrm{nAChR}$ and from HEK-293 cells expressing the chicken chimeric $\alpha 7-5 \mathrm{HT}_{3}$ neuronal $\mathrm{nAChR}$. These results indicate that prorocentrolide- $\mathrm{A}$ is a direct competitive antagonist in both $\mathrm{nAChR}$ subtypes, although much less active than previously-examined cyclic imine toxins and the $\alpha$-cobratoxin herein studied. As shown in Table 2, prorocentrolide-A exhibited the lowest affinity on the $\alpha 7-5 \mathrm{HT}_{3}$ neuronal $\mathrm{nAChR}$ when compared to the muscle-type $\alpha 1_{2} \beta 1 \gamma \delta$ nAChR.

The higher affinity of prorocentrolide-A to muscle-type $\mathrm{nAChR}$ is an important factor contributing to the acute toxicity of this compound. The acute toxic symptoms observed in mice following prorocentrolide-A administration [29] included a rapid onset for skeletal muscle paralysis from the hind legs and respiratory muscles which led to death due to respiratory arrest. Such actions are likely due to the block of nAChRs in the endplate region of skeletal muscles. There was a critical dose-dependency, below which surviving mice recovered completely. The lack of description of initial hyperactivity periods, following the administration of prorocentrolide-A, probably reflects the poor affinity of the compound to the $\alpha 7 \mathrm{nAChRs}$, here reported. The initial hyperactivity periods characterizing the action of most cyclic imine toxins are likely due to a direct effect on the central nervous system of rodents [48].

Important developments have been made in the structural and molecular characterization of nAChRs and in the understanding of the molecular pharmacological profile of cyclic imine toxins (reviewed in [40]). A major step in our knowledge of the structural determinants came from the X-ray crystal structure of some cyclic imine toxins in complex with the acetylcholine binding protein $(\mathrm{AChBP})[43,49]$. AChBPs are water-soluble pentameric proteins, representing structural and functional homologues of the amino-terminal extracellular ligand-binding domain of nAChRs [49,50]. Well-preserved amino acid residues occurring in the nAChR family are existent in the AChBPs, comprising those that are significant for the ligand binding to agonists such as $\mathrm{ACh}$, carbamylcholine, nicotine, as well as for competitive antagonists, for instance, d-tubocurarine and $\alpha$-BTX [50-56] and, consequently, have similar pharmacological properties.

The complexes of prorocentrolide-A with $\alpha 1_{2} \beta 1 \gamma \delta$ and $\alpha 7 \mathrm{nAChRs} \mathrm{obtained} \mathrm{by} \mathrm{docking} \mathrm{(Figure} 4$ ) show two different binding modes. Prorocentrolide-A interacts mostly through the convex side with the $\alpha 1_{2} \beta 1 \gamma \delta \mathrm{nAChR}$, thus establishing an important number of stabilizing hydrophobic and polar interactions with the neighboring residues (Figure 4, left). The hydrogen bond between the hydroxyl group in position 7 with the side chain of Asp197 also seems to be a key stabilizing interaction. Overall, the numerous favorable interactions and the good shape complementarity between the receptor and the ligand can explain the relative good affinity of prorocentrolide-A for the $\alpha 1_{2} \beta 1 \gamma \delta \mathrm{nAChR}$. On the other hand, prorocentrolide- $\mathrm{A}$ is oriented with its concave side towards the binding site of $\alpha 7 \mathrm{nAChR}$, which limits the number of possible interactions (Figure 4, right). These interactions are observed mainly at the extremities of the ligands (e.g., hydrogen bonds between iminium group and Ser36 and between the hydroxyl in position 14 and Gln116). Therefore, the limited number of interactions and the absence of shape complementarity are responsible for the lower affinity of prorocentrolide- $\mathrm{A}$ for the $\alpha 7 \mathrm{nAChR}$. 
It is worth noting that the hydrogen bond interaction between the iminium group and the backbone of Trp147, a general feature of complexes between spiroimine toxins and nAChRs, is absent from the complexes of prorocentrolide-A with the $\mathrm{nAChRs}$ studied. These results also evidenced the originality of prorocentrolide-A in terms of chemical structure and $\mathrm{AChR}$ binding mode, which is completely different from those of agonists (e.g., acetylcholine), or other known antagonists (e.g., spiroimine toxins, $\alpha$-cobratoxin) of nAChRs.

\section{Conclusions}

The present study is the first to show that prorocentrolide-A blocks the Torpedo muscle-type $\alpha 1_{2} \beta 1 \gamma \delta \mathrm{nAChR}$ and the human $\alpha 7 \mathrm{nAChR}$ incorporated or expressed, respectively, in Xenopus oocytes. In addition, competitive-binding studies demonstrated that the toxin displaced $\left[{ }^{125} \mathrm{I}\right] \alpha$-BTX from $\alpha 1_{2} \beta 1 \gamma \delta \mathrm{nAChRs}$ from Torpedo electric organ membranes and chimeric $\alpha 7-5 \mathrm{HT}_{3}$ expressed in HEK-293 cells. Prorocentrolide-A exhibited sub-micromolar affinity for the muscle-type nAChR and was more potent than for the neuronal $\alpha 7-5 \mathrm{HT}_{3} \mathrm{nAChR}$. Compared to other cyclic imine toxins, prorocentrolide- $\mathrm{A}$ is the less active, and molecular docking calculations showed that this is due, at least in part, to the absence of the characteristic hydrogen bond between the iminium group of prorocentrolide-A and the backbone carbonyl group of Trp147 in the receptor that is present in all other cyclic imine toxins.

\section{Materials and Methods}

\subsection{Materials and Reagents}

$\left[{ }^{125} \mathrm{I}\right] \alpha$-Bungarotoxin $\left(\left[{ }^{125} \mathrm{I}\right] \alpha\right.$-BTX) (210-250 Ci·mmol $\left.{ }^{-1}\right)$ and the scintillation solution (Ultima Gold F) were purchased from PerkinElmer (Courtaboeuf, France). Ethyl-3-amino benzoate methanesulfonate, ethylene diamine tetraacetic acid (EDTA), acetylcholine chloride, tricaine, and other chemicals were from Sigma-Aldrich (Saint Quentin Fallavier, France), or other standard sources. The $\alpha$-cobratoxin from Naja kaouthia was obtained by recombinant expression, refolded, and purified in our laboratory, as described previously (see [57]).

\subsection{Animals and Biological Materials}

Adult female Xenopus laevis frogs were purchased at the Centre de Ressources Biologiques Xenopes-CNRS (Université de Rennes 1, Rennes, France), and Torpedo marmorata fish at the Service Modeles Biologiques of the Station Biologique de Roscoff (Roscoff, France). All animal studies were performed in accordance with the guidelines established by the French Council on animal care "Guide for the Care and Use of Laboratory Animals": EEC86/609 Council Directive-Decree 2001-131. The protocols were approved by the French Departmental Direction of Animal Protection (No. A91-453 to Rómulo Aráoz) and the CNRS animal care and use committee. All experiments were approved by the Animal Care and Use Committee of the French Ministry of National Education, High Education and Research (identification code: APAFIS\#5310-2016042016067330 v3; date of approval: 10 November 2016).

The cDNAs coding for chick chimeric $\alpha 7-5 \mathrm{HT}_{3}$ and human $\alpha 7 \mathrm{nAChR}$ were kindly provided by Dr. Pierre-Jean Corringer (Pasteur Institute, Paris, France), and by Professor Isabel Bermudez (Oxford Brookes University, Oxford, UK). Prorocentrolide-A was obtained from extracts of cultured Prorocentrum lima dinoflagellates, isolated at Sesoko Island, Okinawa, Japan, prepared as previously reported [29], and provided by Professor Takeshi Yasumoto. Figure 5, shows a liquid chromatography-mass spectrometry (LC-MS) chromatogram of the sample used in the present experiments. The purity of the sample was further checked by thin layer chromatography which showed only a single spot (not shown). 


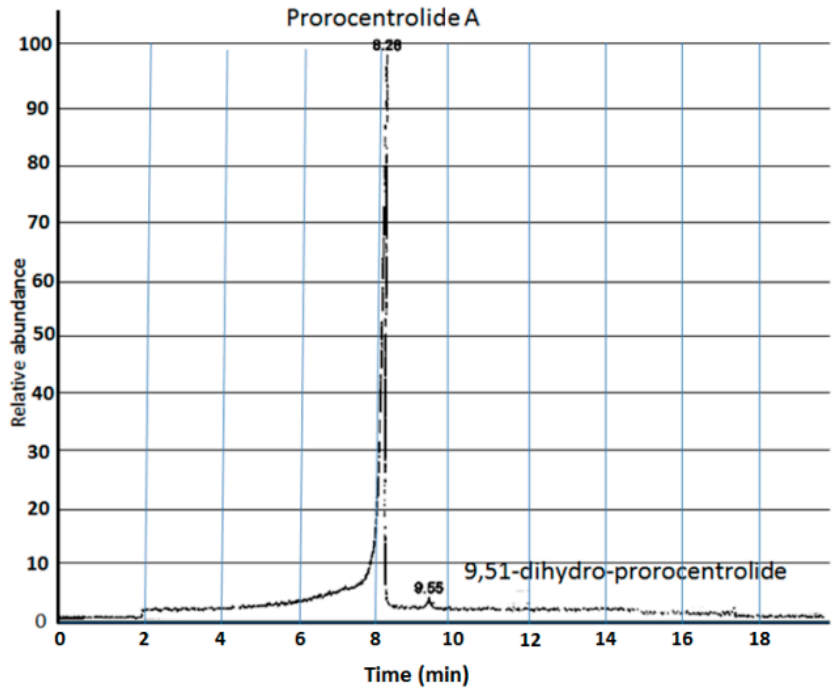

Figure 5. LC-MS chromatogram of the sample used in the experiments here reported. Note the relative abundance of prorocentrolide-A. The small peak component revealed at $9.55 \mathrm{~min}$ corresponds to the 9,51-dihydroprorocentrolide.

\subsection{Expression of the Human $\alpha 7 n A C h R$ in Xenopus Oocytes}

Oocytes were removed from mature female Xenopus laevis frogs under anesthesia, as previously described [41], and placed in a medium devoid of calcium and containing (in $\mathrm{mM}$ ): $\mathrm{NaCl}, 88 ; \mathrm{KCl}, 2.5$; $\mathrm{MgCl}_{2}, 1$; and HEPES, 5 (pH 7.6). After substantial washing with this solution, oocytes were transferred to a Barth's solution containing $(\mathrm{mM}): \mathrm{NaCl}, 88 ; \mathrm{KCl}, 1 ; \mathrm{MgSO}_{4}, 0.33 ; \mathrm{CaCl}_{2}, 0.41 ; \mathrm{MgSO}_{4}, 0.82$; $\mathrm{Ca}\left(\mathrm{NO}_{3}\right)_{2}, 0.33 ; \mathrm{NaHCO}_{3}, 2.4$; and HEPES, $10(\mathrm{pH}=7.2)$ supplemented with $0.1 \mu \mathrm{g} \cdot \mathrm{mL}^{-1}$ kanamycine. Selected oocytes (stage V-VI) were manually defolliculated, and microinjected with the aid of a Nanoliter 2000 Micro4 Controller (World Precision Instruments, Inc., Hertfordshire, UK) with $50 \mathrm{~nL}$ of human $\alpha 7$ mRNA $\left(0.1 \mu \mathrm{g} \cdot \mu \mathrm{L}^{-1}\right)$. Microinjected oocytes were incubated at $18{ }^{\circ} \mathrm{C}$ in Barth's solution, and voltage-clamp recordings were performed 3-4 days later.

\subsection{Microtransplantation of Torpedo Muscle-Type nAChR to Xenopus Oocytes}

Surgical removal of the electric organs of Torpedo marmorata fish was performed under $0.03 \%$ tricaine anaesthesia diluted in seawater. Torpedo electric organs were sliced and purified membranes enriched in the $\alpha 1_{2} \beta 1 \gamma \delta \mathrm{nAChR}$ were made at $4{ }^{\circ} \mathrm{C}$ in $5 \mathrm{mM}$ glycine, using methods described previously $[43,58]$. Aliquots of the purified membranes were stored at $-80{ }^{\circ} \mathrm{C}$ until use. Microtransplantation of Torpedo $\mathrm{nAChR}[58,59]$ consisted in a single microinjection of a membrane suspension (50 $\mathrm{nL}$ at $3.5 \mathrm{mg} \cdot \mathrm{mL}^{-1}$ protein) into the oocyte cytoplasm using a Nanoliter 2000 Micro4 Controller mounted on a microscope (World Precision Instruments, Inc., Hertfordshire, UK), as previously described [43].

\subsection{Voltage-Clamp Recordings in Xenopus Oocytes}

A two-microelectrode voltage-clamp amplifier (OC-725B, Warner Instrument Corp., Hamden, CT, USA) was used to record currents flowing through nAChRs upon activation or inhibition. The voltage and current microelectrodes were filled with a solution of $3 \mathrm{M} \mathrm{KCl}$ and had tip resistances comprised between 0.5 and $1.5 \mathrm{M} \Omega$. Oocytes were voltage-clamped at $-60 \mathrm{mV}$ holding membrane potential. A pCLAMP-9/Digidata-1322A system (Molecular Devices, Union City, CA, USA) was used for data acquisition and recording. The recording chamber had a capacity of $300 \mu \mathrm{L}$, and was superfused at a rate of $8 \mathrm{~mL} \cdot \mathrm{min}^{-1}$ at $20{ }^{\circ} \mathrm{C}$ with a modified Ringer's solution containing $(\mathrm{mM}): \mathrm{NaCl}, 100$; $\mathrm{KCl}, 2.8 ; \mathrm{MgCl}_{2}, 1 ; \mathrm{BaCl}_{2}, 0.3$; and HEPES, 5 (pH 7.4), where $\mathrm{BaCl}_{2}$ replacement to $\mathrm{CaCl}_{2}$ prevents 
secondary activation of $\mathrm{Ca}^{2+}$-dependent chloride current $[41,60]$. A multi-valve perfusion system (VC-6, Warner Instruments Corp., Hamden, CT, USA) controlled by a PC computer was used for exchanging solutions, and to perfuse $\mathrm{ACh}$ or prorocentrolide-A. ACh was perfused during $3 \mathrm{~s}$ periods in oocytes expressing the human $\alpha 7 \mathrm{nAChR}$, and for $15 \mathrm{~s}$ periods in oocytes having incorporated the Torpedo $\alpha 1_{2} \beta 1 \gamma \delta \mathrm{nAChR}$ into their membrane. A 3 min interval was used between consecutive ACh applications, to ensure $\mathrm{nAChR}$ recovery from desensitization. Dose-response inhibition curves were constructed, as detailed previously [42] using GraphPad Prism 6.05 (GraphPad Software, Inc., San Diego, CA, USA, 2013) software.

\subsection{Expression of nAChRs in Human Embryonic Kidney Cells and Binding Assays}

The chimeric chick cDNA of the $\alpha 7-5 \mathrm{HT} 3 \mathrm{nAChR}$ was transfected into human embryonic kidney (HEK-293) cells by methods previously described [61,62]. Briefly, the cDNA (15 $\mu$ g of $\left.\alpha 7-5 \mathrm{HT}_{3}\right)$ was transfected by calcium precipitation with a meticulous $\mathrm{pH}$ control (6.95). Cells were placed at $37^{\circ} \mathrm{C}$ under $5 \% \mathrm{CO}_{2}$, and $48 \mathrm{~h}$ after transfection were collected in a phosphate-buffered saline (PBS) with $5 \mathrm{mM}$ EDTA, and suspended in $3 \mathrm{~mL} /$ plate of this buffer for binding experiments. Cell density was adjusted to bind specifically about $10 \%$ of the radioligand.

Binding assays with Torpedo or $\alpha 7-5 \mathrm{HT}_{3} \mathrm{nAChRs}$ were performed at equilibrium on 96-well plates. Membranes were incubated for $4 \mathrm{~h}$ with distinct concentrations of prorocentrolide-A or $\alpha$-cobratoxin and $\left[{ }^{125} \mathrm{I}\right] \alpha$-BTX $(0.5-1 \mathrm{nM})$. Nonspecific binding was performed in the presence of $1 \mu \mathrm{M} \alpha$-cobratoxin. All the reactions were stopped by filtration of the 96-well simultaneously through a GF/C plate pre-soaked in $0.5 \%$ polyethylenimine, using a FilterMate harvester (PerkinElmer, France). The filters were washed twice with ice-cold buffer (PBS), dried and the bound radioactivity was counted, after the addition of $25 \mu \mathrm{L}$ of MicroScint 0 per well, by scintillation spectrometry on a TopCount beta counter (PerkinElmer, France). $\mathrm{IC}_{50}$ values were determined by fitting the competition data by the empirical Hill's equation and converting to Ki constants using the equation: $\mathrm{Ki}=\mathrm{IC}_{50} /\left(1+\mathrm{L}^{*} / \mathrm{Kd}\right)[63]$. The $\mathrm{Kd}$ for $\alpha$-BTX was $50 \mathrm{pM}$ and $5 \mathrm{nM}$ on muscle-type and $\alpha 7$ receptors, respectively. All experiments were performed at least three times in duplicate.

\subsection{Molecular Modeling}

Homology models of the extracellular domain of human $\alpha 7$ and Torpedo $\alpha 1_{2} \beta 1 \gamma \delta$ nAChRs subtypes were constructed using Modeller [64], and the Aplysia californica acetylcholine binding protein (AChBP) crystal structure as a template (Protein Data Bank code 2WZY) [43]. Three-dimensional structures of the ligand were generated using Corina 3.6 (Molecular Networks GmbH, Erlangen, Germany, 2016). The docking procedure was carried out in two steps: (i) conformational search of all possible prorocentrolide stereoisomers, using MacroModel (Schrödinger LLC, Portland, OR, USA) and (ii) molecular docking using Gold (Cambridge Crystallographic Data Centre, Cambridge, UK) and the GoldScore scoring function of the resulting conformers at the subunit interfaces of $\alpha 7$ and $\alpha 1_{2} \beta 1 \gamma \delta$ homology models. The binding site, defined as a $20 \AA$ radius sphere, was centered on the backbone oxygen atom of Trp147. All other parameters had default values. Initial docking calculations provided no useful results due to the unusual size of the ligand and binding site hindering by the $C$ loop. A second round of docking was carried out with the C loop (residues RFYECCKEPY and VYYTCCPDTPY, respectively) removed. The C loop was reconstructed afterwards using Modeller [63] in the presence of the ligand in the binding site. The receptor-ligand complex images were produced using UCSF Chimera [65].

Acknowledgments: This work was supported by the Agence Nationale de la Recherche (France) by Grant ANR-12-ASTR-0037-AQUANEUROTOX, and by Interreg AlertoxNet EAPA-317-2016.

Author Contributions: T.Y., R.A., D.S., B.I.I., and J.M. conceived and designed the experiments; M.A., and R.A., performed the experiments; T.Y. provided the prorocentrolide-A; B.I.I. carried out the molecular modeling study; and M.A., R.A., B.I.I., D.S., and J.M. wrote the article.

Conflicts of Interest: The authors declare no conflict of interest. 


\section{References}

1. Murray, S.; Ip, C.L.C.; Moore, R.; Nagahama, Y.; Fukuyo, Y. Are prorocentroid dinoflagellates monophyletic? A study of 25 species based on nuclear and mitochondrial genes. Protist 2009, 160, 245-264. [CrossRef] [PubMed]

2. Hoppenrath, M.; Chomérat, N.; Horiguchi, T.; Schweikert, M.; Nagahama, Y.; Murray, S. Taxonomy and phylogeny of the benthic Prorocentrum species (Dinophyceae)—A proposal and review. Harmful Algae 2013, 27, 1-28. [CrossRef]

3. Nagahama, Y.; Murray, S.; Tomaru, A.; Fukuyo, Y. Species boundaries in the toxic dinoflagellate Prorocentrum lima (Dinophyceae, Prorocentrales), based on morphological and phylogenetic characters. J. Phycol. 2011, 47, 178-189. [CrossRef] [PubMed]

4. McLachlan, J.L.; Marr, J.C.; Conlon-Kelly, A.; Adamson, A. Effects of nitrogen concentration and cold temperature on DSP-toxin concentrations in the dinoflagellate Prorocentrum lima (Prorocentrales, Dinophyceae). Nat. Toxins 1994, 2, 263-270. [CrossRef] [PubMed]

5. Cembella, A.D. Occurrence of okadaic acid, a major diarrheic shellfish toxin, in natural populations of Dinophysis spp. from the eastern coast of North America. J. Appl. Phycol. 1989, 1, 307-310. [CrossRef]

6. Li, L.X.; Tang, J.Q.; Yang, W.D.; Liu, J.S.; Zhang, J.J.; Li, H.Y. Studies on toxin production of Prorocentrum lima. Asian J. Ecotoxicol. 2009, 4, 745-750.

7. Murakami, Y.; Oshima, Y.; Yasumoto, T. Identification of okadaic acid as a toxic component of a marine dinoflagellate Prorocentrum lima. Nippon Suisan Gakkaishi 1982, 48, 69-72. [CrossRef]

8. Barbier, M.; Amzil, Z.; Mondeguer, F.; Bhaud, Y.; Soyer-Gobillard, M.-O.; Lassus, P. Okadaic acid and PP2A cellular immunolocalization in Prorocentrum lima (Dinophyceae). Phycologia 1999, 38, 41-46. [CrossRef]

9. Hu, T.; Marr, J.; deFreitas, A.S.W.; Quilliam, M.A.; Walter, J.A.; Wright, J.L.C.; Pleasance, S. New diol esters of okadaic acid isolated from cultures of the dinoflagellates Prorocentrum lima and P. concavum. J. Nat. Prod. 1992, 55, 1631-1637. [CrossRef]

10. Yasumoto, T.; Murata, M.; Lee, J.S.; Torigoe, K. Polyether toxins produced by dinoflagellates. In Mycotoxins and Phycotoxins; Natori, S., Hashimoto, K., Ueno, Y., Eds.; Elsevier: Amsterdam, The Netherlands, 1989; pp. 375-382.

11. Quilliam, M.A.; Ross, N.W. Analysis of diarrhetic shellfish poisoning toxins and metabolites in plankton and shellfish by ion-spray liquid chromatography-mass spectrometry. In Biological and Biotechnological Applications of Electrospray Ionization Mass Spectrometry; Snyder, A.P., Ed.; American Chemical Society: Washington, DC, USA, 1996; pp. 351-364.

12. Lee, T.C.; Fong, F.L.; Ho, K.C.; Lee, F.W. The mechanism of diarrhetic shellfish poisoning toxin production in Prorocentrum spp.: Physiological and molecular perspectives. Toxins 2016, 8, 272. [CrossRef] [PubMed]

13. Trainer, V.L.; Moore, L.; Bill, B.D.; Adams, N.G.; Harrington, N.; Borchert, J.; da Silva, D.A.; Eberhart, B.T. Diarrhetic shellfish toxins and other lipophilic toxins of human health concern in Washington state. Mar. Drugs 2013, 11, 1815-1835. [CrossRef] [PubMed]

14. Sosa, S.; Tubaro, A. Okadaic acid and other diarrheic toxins: Toxicological profile. In Marine and Freshwater Toxins; Gopalakrishnakone, P., Haddad, V., Jr., Tubaro, A., Kim, E., Kem, W.R., Eds.; Springer: Dordrecht, The Netherlands, 2016; pp. 147-168.

15. Yasumoto, T.; Murata, M.; Oshima, Y.; Sano, M.; Matsumoto, G.K.; Clardy, J. Diarrhetic shellfish toxins. Tetrahedron 1985, 41, 1019-1025. [CrossRef]

16. Kumagai, M.; Yanagi, T.; Murata, M.; Yasumoto, T.; Kat, M.; Lassus, P.; Rodríguez-Vázquez, J.A. Okadaic acid as the causative toxin of diarrhetic shellfish poisoning in Europe. Agric. Biol. Chem. 1986, 50, 2853-2857.

17. Murata, M.; Shimatani, M.; Sugitani, H.; Oshima, Y.; Yasumoto, T. Isolation and structural elucidation of the causative toxin of the diarrhetic shellfish poisoning. Nippon Suisan Gakkaishi 1982, 48, 549-552. [CrossRef]

18. Dawson, J.F.; Holmes, C.F. Molecular mechanisms underlying inhibition of protein phosphatases by marine toxins. Front. Biosci. 1999, 4, D646-D658. [CrossRef] [PubMed]

19. Bialojan, C.; Takai, A. Inhibitory effect of a marine-sponge toxin, okadaic acid, on protein phosphatases. Specificity and kinetics. Biochem. J. 1988, 256, 283-290. [CrossRef] [PubMed]

20. Takai, A.; Murata, M.; Torigoe, K.; Isobe, M.; Mieskes, G.; Yasumoto, T. Inhibitory effect of okadaic acid derivatives on protein phosphatases. A study on structure-affinity relationship. Biochem. J. 1992, 284, 539-544. [CrossRef] [PubMed] 
21. Suganuma, M.; Fujiki, H.; Suguri, H.; Yoshizawa, S.; Hirota, M.; Nakayasu, M.; Ojika, M.; Wakamatsu, K.; Yamada, K.; Sugimura, T. Okadaic acid: An additional non-phorbol-12-tetradecanoate-13-acetate-type tumor promoter. Proc. Natl. Acad. Sci. USA 1988, 85, 1768-1771. [CrossRef] [PubMed]

22. Fujiki, H.; Suganuma, M. Tumor promotion by inhibitors of protein phosphatases 1 and 2A: The okadaic acid class of compounds. Adv. Cancer Res. 1993, 61, 143-194. [PubMed]

23. Fujiki, H.; Suganuma, M. Unique features of the okadaic acid activity class of tumor promoters. J. Cancer Res. Clin. Oncol. 1999, 125, 150-155. [CrossRef] [PubMed]

24. Nakagama, H.; Kaneko, S.; Shima, H.; Inamori, H.; Fukuda, H.; Kominami, R.; Sugimura, T.; Nagao, M. Induction of minisatellite mutation in NIH $3 \mathrm{~T} 3$ cells by treatment with the tumor promoter okadaic acid. Proc. Natl. Acad. Sci. USA 1997, 94, 10813-10816. [CrossRef] [PubMed]

25. Rogers, C.G.; Heroux-Metcalf, C.; Langlois, I. Evaluation of cytotoxicity and genotoxicity of okadaic acid, a nonphorbol ester type tumor promoter, in V79 Chinese hamster lung cells. Toxicol. In Vitro 1994, 8, 269-276. [CrossRef]

26. Fessard, V.; Grosse, Y.; Pfohl-Leszkowicz, A.; Puiseux-Dao, S. Okadaic acid treatment induces DNA adduct formation in BHK21 C13 fibroblasts and HESV keratinocytes. Mutat. Res. 1996, 361, 133-141. [CrossRef]

27. Le Hegarat, L.; Jacquin, A.G.; Bazin, E.; Fessard, V. Genotoxicity of the marine toxin okadaic acid, in human Caco-2 cells and in mice gut cells. Environ. Toxicol. 2006, 21, 55-64. [CrossRef] [PubMed]

28. Valdiglesias, V.; Prego-Faraldo, M.V.; Pásaro, E.; Méndez, J.; Laffon, B. Okadaic Acid: More than a diarrheic toxin. Mar. Drugs 2013, 11, 4328-4349. [CrossRef] [PubMed]

29. Torigoe, K.; Murata, M.; Yasumoto, T.; Iwashita, T. Prorocentrolide, a toxic nitrogenous macrocycle from a marine dinoflagellate, Prorocentrum lima. J. Am. Chem. Soc. 1988, 110, 7876-7877. [CrossRef]

30. Lu, C.-K.; Lee, G.-H.; Huang, R.; Chou, H.-N. Spiro-prorocentrimine, a novel macrocyclic lactone from a benthic Prorocentrum sp. of Taiwan. Tetrahedron Lett. 2001, 42, 1713-1716. [CrossRef]

31. Lu, C.-K.; Chou, H.-N.; Lee, C.-K.; Lee, T.-H. Prorocentin, a new polyketide from the marine dinoflagellate Prorocentrum lima. Org. Lett. 2005, 7, 3893-3896. [CrossRef] [PubMed]

32. Lu, C.-K.; Chen, Y.-M.; Wang, S.-H.; Wu, Y.-Y.; Cheng, Y.-M. Formosalides A and B, cytotoxic 17-membered ring macrolides from a marine dinoflagellate Prorocentrum sp. Tetrahedron Lett. 2009, 50, 1825-1827. [CrossRef]

33. Yang, A.R.; Lee, S.; Yoo, Y.D.; Kim, H.S.; Jeong, E.J.; Rho, J.R. Limaol: A polyketide from the benthic marine dinoflagellate Prorocentrum lima. J. Nat. Prod. 2017, 80, 1688-1692. [CrossRef] [PubMed]

34. Hu, T.; deFreitas, S.W.; Curtis, J.M.; Oshima, Y.; Walter, J.A.; Wright, J.L.C. Isolation and structure of prorocentrolide B, a fast-acting toxin from Prorocentrum maculosum. J. Nat. Prod. 1996, 59, 1010-1014. [CrossRef] [PubMed]

35. Nascimento, S.M.; Mendes, M.C.Q.; Menezes, M.; Rodríguez, F.; Alves-de-Souza, C.; Branco, S.; Riobó, P.; Franco, J.; Nunes, J.M.C.; Huk, M.; et al. Morphology and phylogeny of Prorocentrum caipirignum sp. nov. (Dinophyceae), a new tropical toxic benthic dinoflagellate. Harmful Algae 2017, 70, 73-89. [CrossRef] [PubMed]

36. Molgó, J.; Girard, E.; Benoit, E. Cyclic imines: An insight into this emerging group of bioactive marine toxins. In Phycotoxins: Chemistry and Biochemistry; Botana, L., Ed.; Blackwell Publishing: Iowa, IA, USA, 2007; pp. 319-335.

37. Molgó, J.; Aráoz, R.; Benoit, E.; Iorga, B.I. Cyclic imine toxins: Chemistry, origin, metabolism, pharmacology, toxicology, and detection. In Seafood and Freshwater Toxins. Pharmacology Physiology and Detection, 3rd ed.; Botana, L.M., Ed.; CRC Press: Boca Raton, FL, USA, 2014; pp. 951-990.

38. Otero, A.; Chapela, M.J.; Atanassova, M.; Vieites, J.M.; Cabado, A.G. Cyclic imines: Chemistry and mechanism of action: A review. Chem. Res. Toxicol. 2011, 24, 1817-1829. [CrossRef] [PubMed]

39. Stivala, C.E.; Benoit, E.; Aráoz, R.; Servent, D.; Novikov, A.; Molgó, J.; Zakarian, A. Synthesis and biology of cyclic imine toxins, an emerging class of potent, globally distributed marine toxins. Nat. Prod. Rep. 2015, 32, 411-435. [CrossRef] [PubMed]

40. Molgó, J.; Marchot, P.; Aráoz, R.; Benoit, E.; Iorga, B.I.; Zakarian, A.; Taylor, P.; Bourne, Y.; Servent, D. Cyclic imine toxins from dinoflagellates: A growing family of potent antagonists of the nicotinic acetylcholine receptors. J. Neurochem. 2017, 142 (Suppl. 2), 41-51. [CrossRef] [PubMed]

41. Aráoz, R.; Ouanounou, G.; Iorga, B.I.; Goudet, A.; Alili, D.; Amar, M.; Benoit, E.; Molgó, J.; Servent, D. The neurotoxic effect of 13,19-didesmethyl and 13-desmethyl spirolide C phycotoxins is mainly mediated by nicotinic rather than muscarinic acetylcholine receptors. Toxicol. Sci. 2015, 147, 156-167. [CrossRef] [PubMed] 
42. Couesnon, A.; Aráoz, R.; Iorga, B.I.; Benoit, E.; Reynaud, M.; Servent, D.; Molgó, J. The dinoflagellate toxin 20-methyl spirolide-G potently blocks skeletal muscle and neuronal nicotinic acetylcholine receptors. Toxins (Basel) 2016, 8, 249. [CrossRef] [PubMed]

43. Bourne, Y.; Radić, Z.; Aráoz, R.; Talley, T.T.; Benoit, E.; Servent, D.; Taylor, P.; Molgó, J.; Marchot, P. Structural determinants in phycotoxins and AChBP conferring high affinity binding and nicotinic AChR antagonism. Proc. Natl. Acad. Sci. USA 2010, 107, 6076-6081. [CrossRef] [PubMed]

44. Kharrat, R.; Servent, D.; Girard, E.; Ouanounou, G.; Amar, M.; Marrouchi, R.; Benoit, E.; Molgó, J. The marine phycotoxin gymnodimine targets muscular and neuronal nicotinic acetylcholine receptor subtypes with high affinity. J. Neurochem. 2008, 107, 952-963. [CrossRef] [PubMed]

45. Aráoz, R.; Servent, D.; Molgó, J.; Iorga, B.I.; Fruchart-Gaillard, C.; Benoit, E.; Gu, Z.; Stivala, C.; Zakarian, A. Total synthesis of pinnatoxins $\mathrm{A}$ and $\mathrm{G}$ and a revision of the mode of action of pinnatoxin A. J. Am. Chem. Soc. 2011, 133, 10499-10511. [CrossRef] [PubMed]

46. Corringer, P.J.; Le Novere, N.; Changeux, J.P. Nicotinic receptors at the amino acid level. Annu. Rev. Pharmacol. Toxicol. 2000, 40, 431-458. [CrossRef] [PubMed]

47. Albuquerque, E.X.; Pereira, E.F.; Alkondon, M.; Rogers, S.W. Mammalian nicotinic acetylcholine receptors: From structure to function. Physiol. Rev. 2009, 89, 73-120. [CrossRef] [PubMed]

48. Munday, R. Toxicology of cyclic imines: Gymnodimines, spirolides, pinnatoxins, pteriatoxins, prorocentrolide, spiro-prorocentroimine and symbioimines. In Seafood and Freshwater Toxins. Pharmacology Physiology and Detection; Botana, L.M., Ed.; CRC Press: Boca Raton, FL, USA, 2008; pp. 581-594.

49. Bourne, Y.; Sulzenbacher, G.; Radić, Z.; Aráoz, R.; Reynaud, M.; Benoit, E.; Zakarian, A.; Servent, D.; Molgó, J.; Taylor, P.; et al. Marine macrocyclic imines, pinnatoxins A and G: Structural determinants and functional properties to distinguish neuronal $\alpha 7$ from muscle $\alpha 1_{2} \beta 1 \gamma \delta$ nAChRs. Structure 2015, 23, 1106-1115. [CrossRef] [PubMed]

50. Brejc, K.; van Dijk, W.J.; Klaassen, R.V.; Schuurmans, M.; van Der Oost, J.; Smit, A.B.; Sixma, T.K. Crystal structure of an ACh-binding protein reveals the ligand-binding domain of nicotinic receptors. Nature 2001, 411, 269-276. [CrossRef] [PubMed]

51. Sixma, T.K.; Smit, A.B. Acetylcholine binding protein (AChBP): A secreted glial protein that provides a high-resolution model for the extracellular domain of pentameric ligand-gated ion channels. Annu. Rev. Biophys. Biomol. Struct. 2003, 32, 311-334. [CrossRef] [PubMed]

52. Celie, P.H.; van Rossum-Fikkert, S.E.; van Dijk, W.J.; Brejc, K.; Smit, A.B.; Sixma, T.K. Nicotine and carbamylcholine binding to nicotinic acetylcholine receptors as studied in AChBP crystal structures. Neuron 2004, 41, 907-914. [CrossRef]

53. Hansen, S.B.; Talley, T.T.; Radić, Z.; Taylor, P. Structural and ligand recognition characteristics of an acetylcholine-binding protein from Aplysia californica. J. Biol. Chem. 2004, 279, 24197-24202. [CrossRef] [PubMed]

54. Hansen, S.B.; Sulzenbacher, G.; Huxford, T.; Marchot, P.; Taylor, P.; Bourne, Y. Structures of Aplysia AChBP complexes with nicotinic agonists and antagonists reveal distinctive binding interfaces and conformations. EMBO J. 2005, 24, 3635-3646. [CrossRef] [PubMed]

55. Dellisanti, C.D.; Yao, Y.; Stroud, J.C.; Wang, Z.Z.; Chen, L. Crystal structure of the extracellular domain of $\mathrm{nAChR} \alpha 1$ bound to $\alpha$-bungarotoxin at $1.94 \AA$ resolution. Nat. Neurosci. 2007, 10, 953-962. [CrossRef] [PubMed]

56. Hibbs, R.E.; Sulzenbacher, G.; Shi, J.; Talley, T.T.; Conrod, S.; Kem, W.R.; Taylor, P.; Marchot, P.; Bourne, Y. Structural determinants for interaction of partial agonists with acetylcholine binding protein and neuronal $\alpha 7$ nicotinic acetylcholine receptor. EMBO J. 2009, 28, 3040-3051. [CrossRef] [PubMed]

57. Antil, S.; Servent, D.; Ménez, A. Variability among the sites by which curaremimetic toxins bind to Torpedo acetylcholine receptor, as revealed by identification of the functional residues of alpha-cobratoxin. J. Biol. Chem. 1999, 274, 34851-34858. [CrossRef] [PubMed]

58. Hill, J.A., Jr.; Nghiem, H.O.; Changeux, J.P. Serine-specific phosphorylation of nicotinic receptor associated 43K protein. Biochemistry 1991, 30, 5579-5585. [CrossRef] [PubMed]

59. Miledi, R.; Palma, E.; Eusebi, F. Microtransplantation of neurotransmitter receptors from cells to Xenopus oocyte membranes: New procedure for ion channel studies. Methods Mol. Biol. 2006, 322, 347-355. [PubMed]

60. Sands, S.B.; Costa, A.C.; Patrick, J.W. Barium permeability of neuronal nicotinic receptor $\alpha 7$ expressed in Xenopus oocytes. Biophys. J. 1993, 65, 2614-2621. [CrossRef] 
61. Eisèle, J.L.; Bertrand, S.; Galzi, J.L.; Devillers-Thiery, A.; Changeux, J.P.; Bertrand, D. Chimaeric nicotinic-serotonergic receptor combines distinct ligand binding and channel specificities. Nature 1993, 366, 479-483. [CrossRef] [PubMed]

62. Servent, D.; Winckler-Dietrich, V.; Hu, H.Y.; Kessler, P.; Drevet, P.; Bertrand, D.; Menez, A. Only snake curaremimetic toxins with a fifth disulfide bond have high affinity for the neuronal $\alpha 7$ nicotinic receptor. J. Biol. Chem. 1997, 272, 24279-24286. [CrossRef] [PubMed]

63. Cheng, Y.; Prusoff, W.H. Relationship between the inhibition constant (K1) and the concentration of inhibitor which causes 50 per cent inhibition (i50) of an enzymatic reaction. Biochem. Pharmacol. 1973, 22, 3099-3108. [PubMed]

64. Webb, B.; Sali, A. Protein Structure Modeling with MODELLER. Methods Mol. Biol. 2017, 1654, 39-54. [PubMed]

65. Pettersen, E.F.; Goddard, T.D.; Huang, C.C.; Couch, G.S.; Greenblatt, D.M.; Meng, E.C.; Ferrin, T.E. UCSF Chimera-A visualization system for exploratory research and analysis. J. Comput. Chem. 2004, 25, 1605-1612. [CrossRef] [PubMed]

(C) 2018 by the authors. Licensee MDPI, Basel, Switzerland. This article is an open access article distributed under the terms and conditions of the Creative Commons Attribution (CC BY) license (http://creativecommons.org/licenses/by/4.0/). 